\title{
海産環状グアニジン系天然物の全合成及び新規グアニジン型不斉有機分子触媒の開発
}

\author{
長澤和夫
}

\section{Total Synthesis of Marine Cyclic Guanidine Compounds and Development of Novel Guanidine Type Asymmetric Organocatalysts}

\author{
Kazuo NAGASAWA \\ The Institute of Molecular and Cellular Biosciences, The University of Tokyo, \\ 1-1-1 Yayoi, Bunkyo-ku, Tokyo 113-0032, Japan
}

(Received February 21, 2003)

\begin{abstract}
Crambescidins and batzelladines, novel marine guanidine alkaloids, have unique pentacyclic and tricyclic guanidine core structures, respectively. They display a considerable array of biological activity and not surprisingly have attracted considerable synthetic interest. The first total synthesis of crambescidin 359 (7) and stereoselective total synthesis of batzelladine D (11) were accomplished based on a successive 1,3-dipolar cycloaddition reaction strategy. During synthetic studies of 7, the absolute stereochemistry was revealed. Based on the structure of 7, the novel $C_{2}-$ symmetric pentacyclic guanidine compounds 69a- d were designed and synthesized as guanidine organocatalysts. The catalyst 69b works efficiently as an asymmetric catalyst of the alkylation reaction of the glycynate-benzophenone Schiff base 73, which gives 74 with $80-90 \%$ ee.
\end{abstract}

Key words__ crambescidin 359; batzelladine D; asymmetric guanidine catalyst; phase-transfer catalyst; total synthesis

\section{1. はじめに}

海産天然物には多彩でユニークな化学構造を持 ち, 極めて強い生理活性を有する化合物が数多く存 在する.このため現在, 海産天然物の医薬品への展 開を指向した，合成化学的な見地からの研究が活発 に行われている。 また，海産天然物の持つユニーク な化学構造は, 我々合成化学者に新しい機能を有す る有機化合物をデザインする上で数多くのヒントを 与えてくれる。最近我々は，海産グアニジン系天然 物に着目し，その全合成研究を通じて得られる合成 誘導体の, バイオロジカルツールとしての活用, 及 びケミカルツールとしての活用を視野に入れた研究 を展開している.グアニジン構造は必須アミノ酸の アルギニン中に含まれ，プロトン化されることによ り生ずる共鳴安定化効果のため, 非常に強い塩基性 を示す.1)また，グアニジン化合物は，カルボン酸 やリン酸と水素結合及びイオン結合を介して複合体

東京大学分子細胞生物学研究所（干113-0032 文京区弥 生 1-1-1)

e-mail: nagasawa@iam.u-tokyo.ac.jp

*本総説は, 平成 15 年度日本薬学会奨励賞の受賞を記 念して記述したものである。
を形成することから，カルボン酸などに対するホス 卜化合物としての機能を有する. 実際, 光学活性な グアニジン化合物によるアミノ酸の光学分割が報告

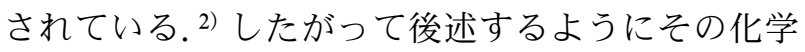
的機能に着目すると, グアニジン化合物を新たな有 機合成化学ツールとして開発することが期待できる.

本論文では，ユニークな構造を有する海産環状グ アニジン系天然物, crambescidin 類, batzelladine 類の合成手法の開発及び全合成研究について述べ, さらに全合成研究で得た知見をもとに，天然物の基 本骨格から設計した新しい有機分子触媒の創製研究 について，最近得られた知見について述べる.

\section{2. 海産グアニジン系天然物}

1989 年, カリブ海産及び紅海産海綿（Ptilocaulis specullifer, Hemimycale sp.) から特異な環状グア二 ジン構造を有する海産天然物 ptilomycalin A (1) が 単離報告された (Fig. 1). ${ }^{3-5)} 1$ は，アセタール構 造を含む対称性のよい 5 環性グアニジン骨格を有 し, これが長鎖メチレン鎖を介しスペルミジンと結 合している. Ptilomycalin A (1) は Candida albicans に対する強い抗菌活性 (MIC, $0.8 \mu \mathrm{M})$, 数種 のガン細胞に対する抗腫瘍活性（P388，（ $\mathrm{IC}_{50} 0.1$ 


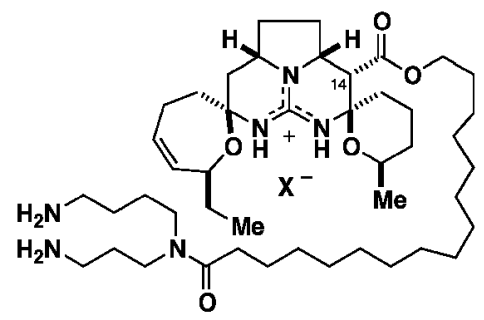

Ptilomycalin A (1)

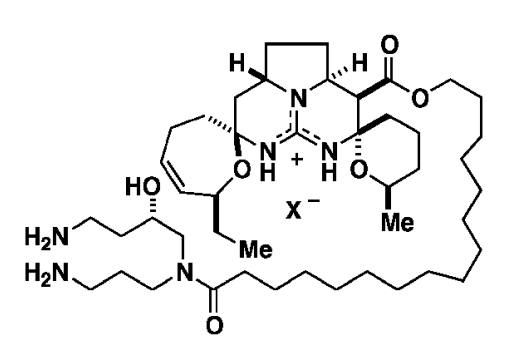

Isocrambescidin 800 (6)

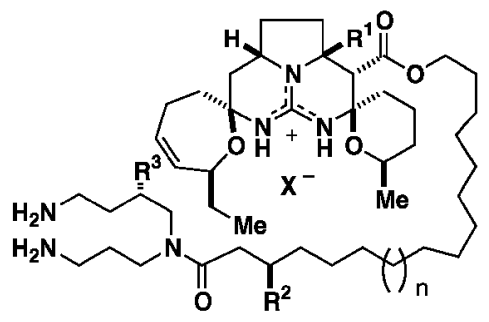

2: $R^{1}=H, R^{2}=O H, R^{3}=H, n=1$

3: $R^{1}=R^{2}=O H, R^{3}=H, n=1$

4: $\mathbf{R}^{1}=\mathbf{R}^{2}=\mathrm{OH}, \mathbf{R}^{3}=\mathrm{H}, \mathbf{n}=\mathbf{2}$

5: $R^{1}=R^{2}=O H, R^{3}=H, n=3$

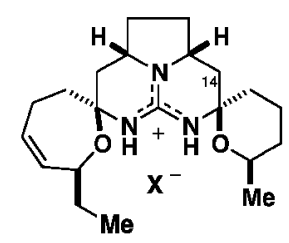

Crambescidin 359 (7)

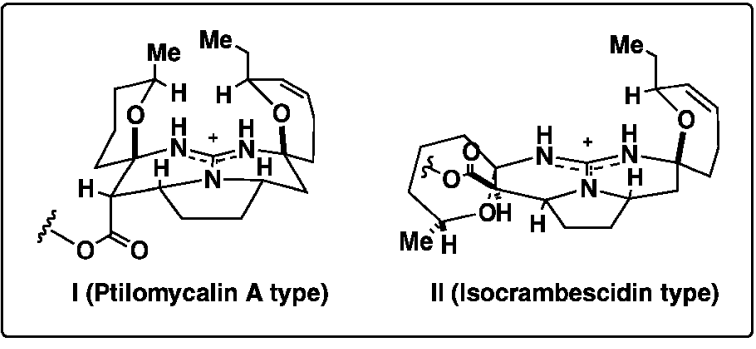

Fig. 1. Marine Pentacyclic Guanidine Compounds

$\left.\mu \mathrm{M}), \quad \mathrm{L} 1210\left(\mathrm{IC}_{50} 0.4 \mu \mathrm{M}\right), \mathrm{KB}\left(\mathrm{IC}_{50} 1.3 \mu \mathrm{M}\right)\right),{ }^{3,4)}$ 酵素阻害活性（非核酸系で唯一 $\mathrm{Ca}^{2+}-\mathrm{ATPase}$ に対

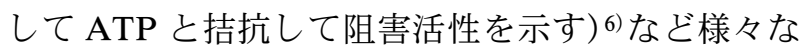
興味深い生物活性が報告されている。その後 1991 年に 1 の類縁化合物である crambescidine 800, 816, 830, $844 （$ 2-5） 及び isocrambescidin $800 （ 6 ）$ が地 中海の海綿 Crambe crambe から単離報告され た. 7,8)これらいずれの類縁化合物も強い抗ウイルス 活性, 抗菌活性, 抗腫瘍活性を示し, 特に crambescidin 816 (3) は強力なカルシウムチャネルブロ ッカーとして作用することが報告されている. ${ }^{8)} し$ かしながら興味深いことに，5環性グアニジン中の ピロリジン環の核間メチレンプロトンが，互いに trans の相対立体配置を有する isocrambescidin 800 （6）は，その cis 類縁体の多くが有する生物活性を ほとんど示さない, 若しくは示しても弱い。これは 恐らく, ptilomycalin A（1）などが有するI型のイ オンポッケトを，6（II 型）は持たないためと考え られる。 ${ }^{9)}$ 他の 5 環性グアニジン骨格を有する類縁 化合物として，1995 年にスペルミジン部位が修飾 された celeromycalin, fromiamycalin が, 10) さらに 2000 年には 1 のスペルミジン部位及び長鎖メチレ ン鎖が完全に欠落した crambescidin 359 (7) ${ }^{11)}$ がそ れぞれ報告されている。

一方, Patil らにより新たな 3 環性グアニジン骨 格を有する天然物 batzelladine 類が報告されている.
1995 年, カリブ海の海綿 Batzella sp. より batzelladine $\mathrm{A}$ - $\mathrm{E}$ (8-12) が単離報告された (Fig. 2).12) Batzelladine A（8）及び B (9) は, ヒト免疫不全 ウイルス（HIV）表層のエンベロープ糖タンパク質 gp120 と細胞膜タンパク質 CD4 との結合を阻害す ることから，新しい作用に基づく抗エイズ薬として の可能性が示唆されている. Batzelladine 類の構造 は, 当初ピロリジン環の核間メチンプロトンが互い にシス相対立体配置を有していると報告されたが, その後 batzelladine A (8), D（11）に関しては, 核間がトランス相対立体配置であることが Snider らにより明らかにされた. ${ }^{13)}$ Batzelladine A-E の構 造類縁化合物として, 1997 年には同種の海綿から

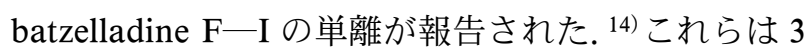
環性グアニジン骨格を 2 個含む構造を持ち, 膜タン パク質 CD4 に会合しているチロシンキナーゼ p56 lck の解離を促進する。これらの構造は当初, batzelladine A-E と比較することにより，いづれ の化合物もすべてピロリジン環の核間メチンプロト ンが互いに trans 相対立体配置を有すると報告され たが，その後の batzelladine F（13）の合成研 究, ${ }^{15-17,22)}$ 及び Overman らの全合成の成功 ${ }^{18)} に よ$ り, batzelladine F（13）の左側 3 環性グアニジン部 に関しては，その相対立体配置が cis 配置であるこ とが明らかとなっている.

これら環状グアニジン化合物の生合成経路につい 


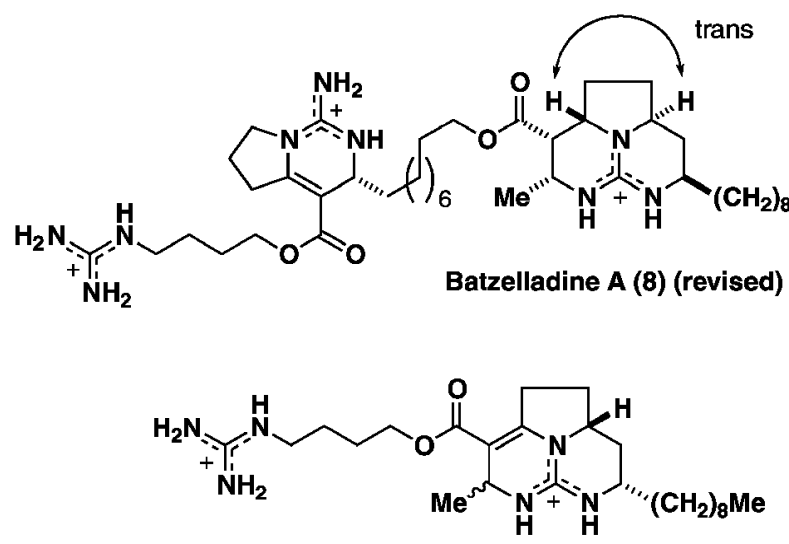

Batzelladine C (10)

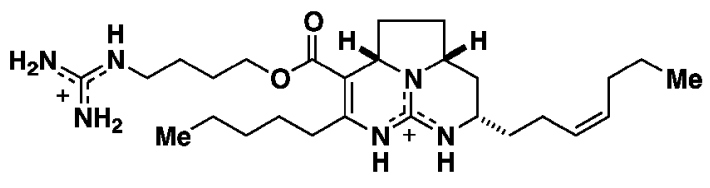

Batzelladine E (12) (revised)

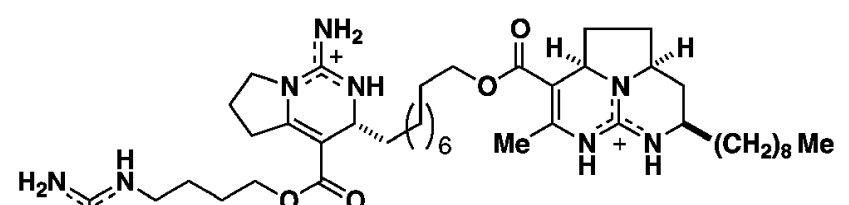

Batzelladine B (9)

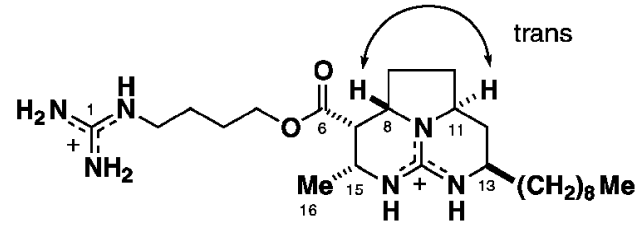

Batzelladine D (11) (revised)

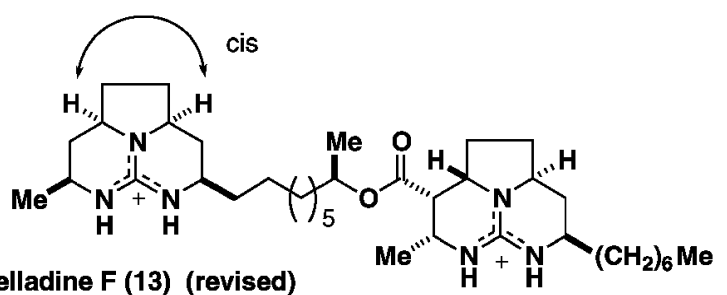

Fig. 2. Marine Tricyclic Guanidine Compounds

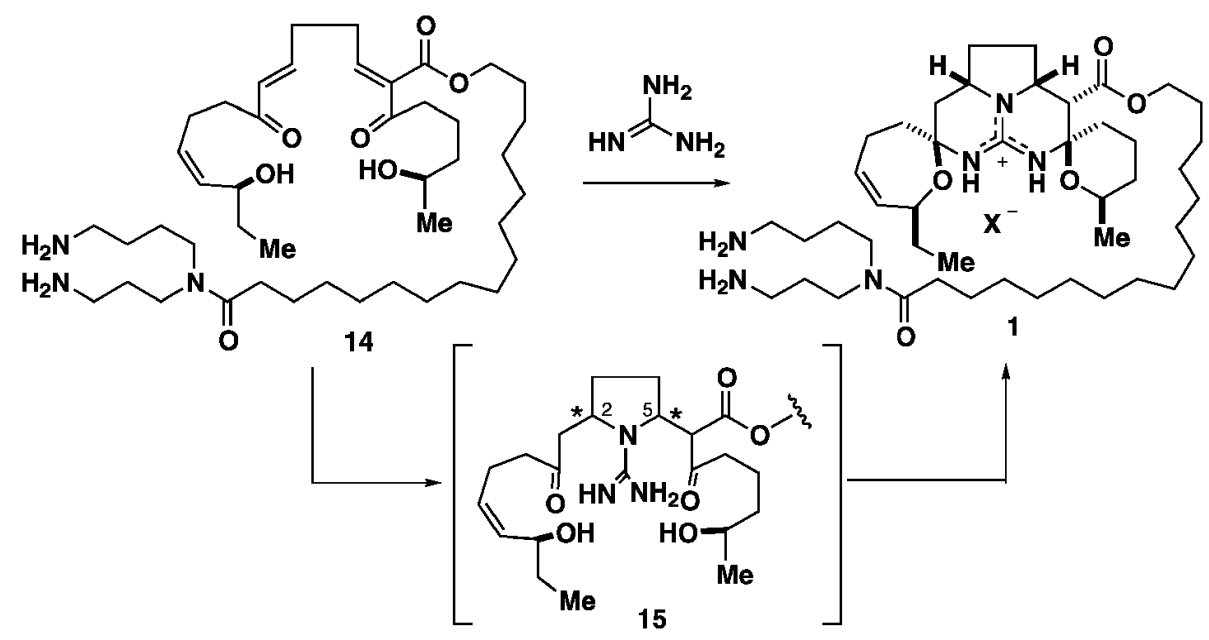<smiles>[R]/C(=C/CC/C=C/C(=O)CCCCCO)C(=O)CCCCO</smiles>

16

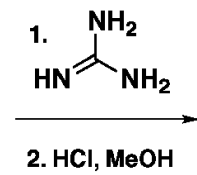

2. $\mathrm{HCl}, \mathrm{MeOH}$

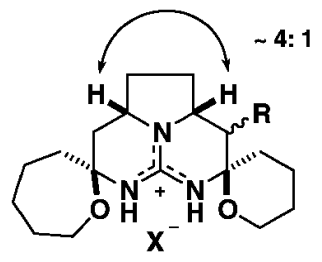

17

Scheme 1. Biomimetic Synthesis of Cyclic Guanidine Compounds

ては, ptilomycalin A（1) を例にすると, ビスエノ ン化合物 14 に対してグアニジンがへテロマイケル 付加し，その後閉環することにより生成すると考え
られている (Batzelladine 類の場合は, 閉環後還元 反応を経る）（Scheme 1)。この生合成経路をもとに Snider, Murphy らは, ビスエノン $\mathbf{1 6}$ に対しグアニ 

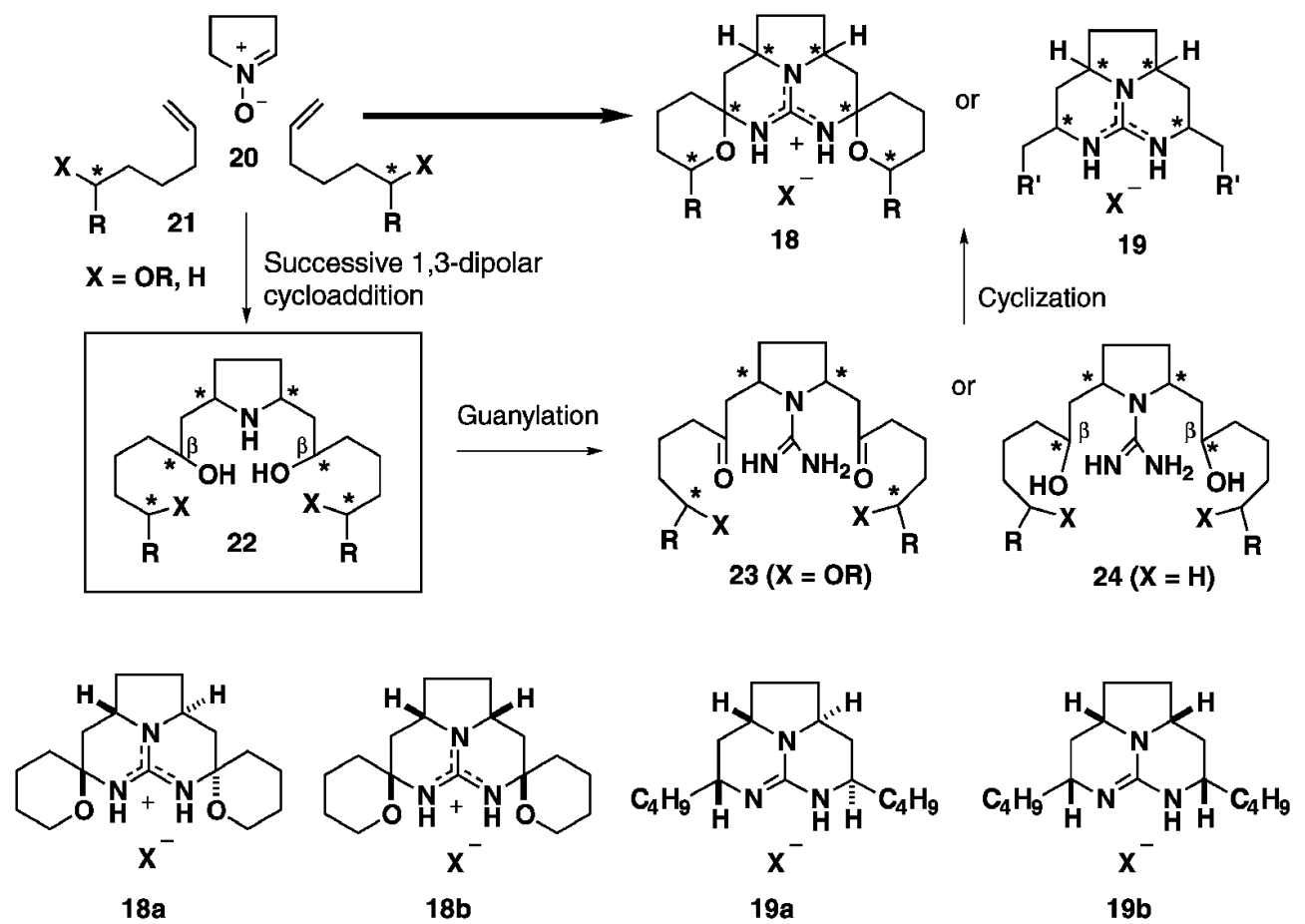

Scheme 2. Retrosynthetic Analysis for Cyclic Guanidine Compounds

ジンを反応させ，その後酸処理することにより 5 環 性グアニジン 17 を得ている。なおこの時, ptilomycalin A 型の cis 体が約 $4: 1$ の選択性で優先 することを見い出している. ${ }^{19,20)}$

我々は非常に興味深い生理活性と, ユニークな骨 格を有する一連の環状グアニジン系天然物の全合成 を目的とし，その生合成経路の反応中間体である 2,5-二置換ピロリジン化合物 15 を共通合成鍵中間 体に設定し, 全合成研究を行うこととした。 そこで まず，環状グアニジン系化合物 $\mathbf{1 8}, 19$ の簡便かつ 立体選択的な合成法の開発を検討することとした (Scheme 2).

3. 環状グアニジン化合物の立体選択的合成法の 開発 21,22$)$

環状グアニジン化合物 18 及び 19 を合成するにあ たり，ピロリジン環の側鎖 $\beta$ 位に酸素官能基を有 する 2,5 二置換ピロリジン 22 を共通合成中間体と して選んだ. また 22 は, 連続的な 1,3-双極子環化 反応を用いることにより立体選択的に合成すること とした。この際, ピロリジン環の側鎖 $\beta$ 位の水酸 基の立体化学を制御することにより, 本手法による batzelladine 類の立体選択的合成への展開を同時に 行えるよう計画した。 そこで次に本合成戦略を基に trans-18a, cis-18b, trans $-19 \mathrm{a}$, cis-19b をそれぞれ立 体選択的に合成することを検討した（Scheme 3). ピロリジンを酸化することにより得られるニトロ ン 20 と, 5-hexene-1-ol 誘導体 25 との 1,3-双極子 環化付加反応によりイソキサゾリジン 26 を位置及 び立体選択的に得た。 26 に対し，Tufariello-Aliの 反応条件 23,24$)$ すなわち, 塩化メチレン中 $0^{\circ} \mathrm{C}$ で mCPBA を反応させたところ, イソキサゾリジン環 が酸化的に開環すると同時に位置選択的にニトロン が再生し 27 が得られた。ついで得られた 27 に対 し, 再度オレフィン 25 を反応させたところ, 立体 選択的にイソキサゾリン $\mathbf{2 8}$ が得られた。この際 $\mathbf{2 5}$ は, 27 の立体障害の少ない 5 位側鎖と反対側から エキソ型で接近し， 28 の 2 位及び側鎖 $\beta$ 位の立体 化学を制御することができた。得られた 28 は, 水 素雾囲気下, パラジウム炭素により $\mathrm{N}-\mathrm{O}$ 結合を還 元し $C_{2}$ 対称な 2,5-二置換ピロリジン 29 を得た. そこで 29 に対しグアニジノ基を導入し，ついで側 鎖上の 2 つ水酸基を TPAPにより酸化しジケト ンとした後, 塩酸一メタノールと反応させることに より，目的とする trans-5 環性グアニジン 18a を合 成することができた。一方 $18 \mathrm{~b}$ は，先に得られた 中間体 $\mathbf{2 8}$ より合成した。すなわちイソキサゾリジ 


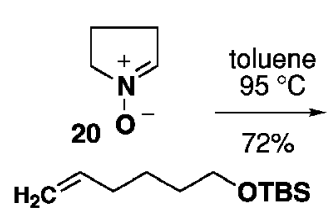

25

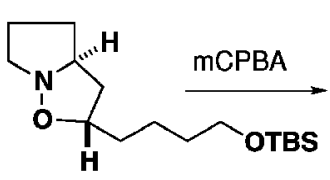

26
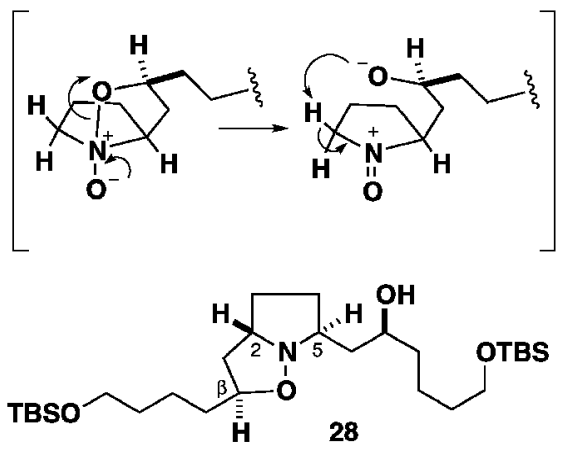

H 28

27

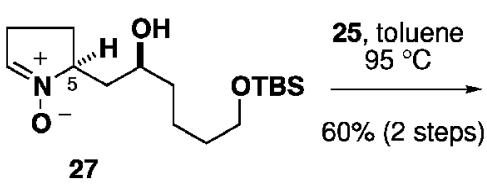

toluene

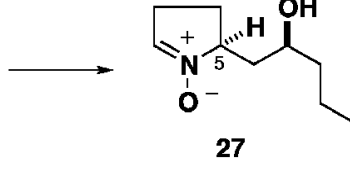

$60 \%$ (2 steps)

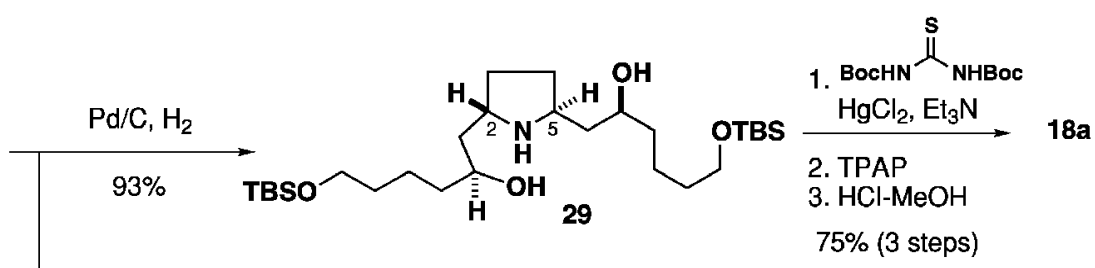

mCPBA

$\underbrace{}_{\mathrm{H}_{\mathbf{H}}}$

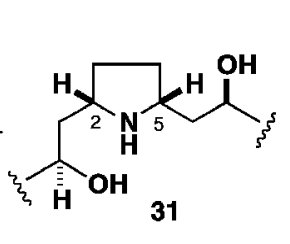

$\underset{\mathrm{HgCl}_{2}, \mathrm{Et}_{3} \mathrm{~N}}{\stackrel{\text { 1. }}{\mathrm{BocHN}_{\text {2. } \mathrm{TPAP}}}} \mathbf{s}$
3. $\mathrm{HCl}-\mathrm{MeOH}$
$65 \%$ (3 steps)

Scheme 3. Stereoselective Synthesis of $\mathbf{1 8 a}$ and $\mathbf{1 8 b}$

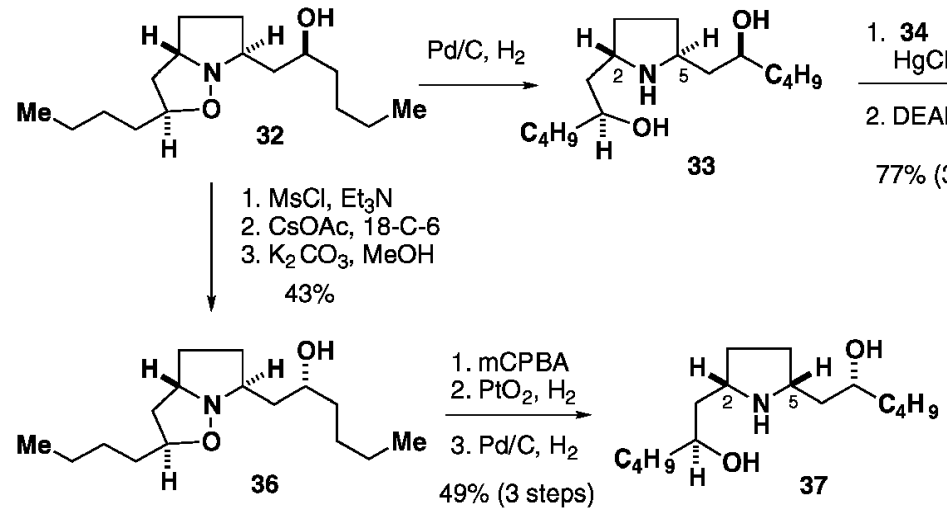

Scheme 4. Stereoselective Synthesis of 19a and 19b

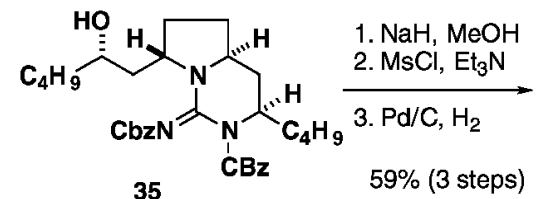

1. 34

$\mathrm{HgCl}_{2}, \mathrm{Et}_{3} \mathrm{~N}$

2. DEAD, $P$ Ph

3. $\mathrm{NaH}, \mathrm{MeOH} \longrightarrow 19 \mathrm{~b}$

4. $\mathrm{MsCl}, \mathrm{Et}_{3} \mathrm{~N}$

$52 \%(5$ steps)

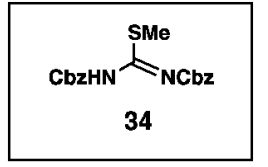

ン 28 に対し再度 mCPBA を作用させニトロン 30 を位置選択的に得，ついで酸化白金触媒を用いニト ロンを立体選択的に還元することによりヒドロキシ アミンとし, 続くパラジウム炭素触媒下ヒドロキシ ルアミンを還元し， 2,5 位の立体化学が cis 配置に 制御されたピロリジン 31 を得た。 そこで 31 に対し 先と同様の 3 行程の変換反応を行い, $c i s-5$ 環性グ アニジン 18b を立体選択的に合成することができ た.
3 環性グアニジン 19 も，ほぼ同様の合成ルート を用いて立体選択的に合成することができた (Scheme 4). すなわち, ニトロン 20 と 1-hexene と の連続的 1,3-双極子環化反応を用いることにより イソキサゾリジン 32 を経て, 立体選択的にピロリ ジン化合物 33 を得, 33 に対しグアニジノ基を導入 し，ついで $\mathrm{DEAD}, \mathrm{PPh}_{3}$ を反応させることにより 閉環反応が進行し， 2 環性グアニジン化合物 35 が 得られた。次に $\mathbf{3 5}$ の 2 つ $\mathrm{Cbz}$ 基のうち 1 つを選 


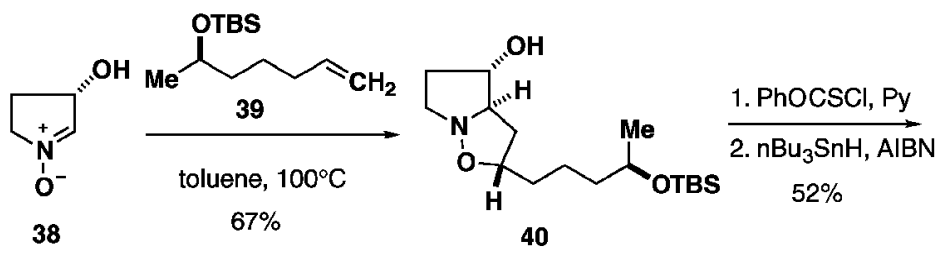

40

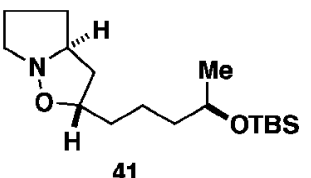

41

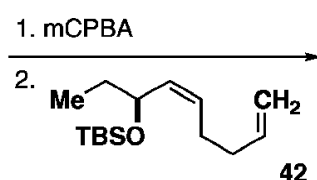

$65 \%$ (2steps)
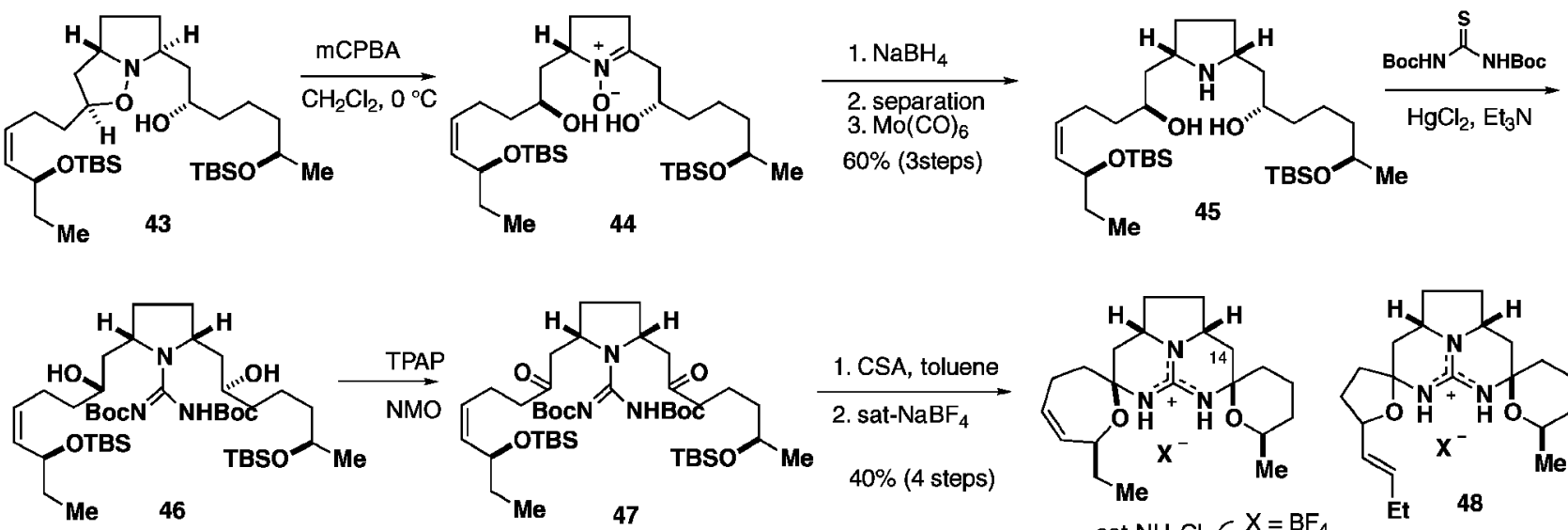

sat- $-\mathrm{NH}_{4} \mathrm{Cl}\left(\begin{array}{l}\mathrm{X}=\mathrm{BF} \\ \mathrm{X}=\mathrm{Cl}\end{array}\right.$

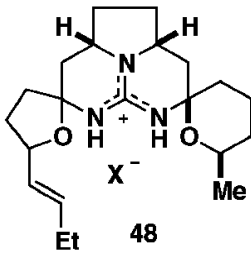

Crambescidin 359 (7)

Scheme 5. Total Synthesis of Crambescidin 359 (7)

択的に加水分解し, ${ }^{25)} 2$ 級水酸基をメシル化したと ころ同時に閉環反応が進行して 3 環性グアニジン化 合物を得ることができた。最後に水素雾囲気下，パ ラジウム炭素により残りの Cbz 基の脱保護を行い 19a を得ることができた。一方 19b の合成は以下の ように行つた。 まず 32 の 2 級水酸基の立体化学を 以下の 3 行程により反転した。 すなわち水酸基を入 シル化後, 水酸化セシウムによる立体反転を伴うア セトキシ基の導入反応を行い, 続くアセチル基の加 水分解反応により 36 を得た。 この水酸基の立体化 学の反転の際, 光延反応による方法も試みたが, こ の場合はイソキサゾリジン環の開環を伴う副反応が 進行し, 複雑な生成物を与えた. 得られた 36 は先 と同様, mCPBAによるニトロンの再生と続く 2 段 階の還元反応によりピロリジン環 5 位の立体化学を 反転し, メソ 2,5 二置換ピロリジン 37 へと変換し た. 最後に前述の 5 行程により, $c i s-3$ 環性グアニ ジン 19bを得ることができた.

そこで本合成手法を基盤とし，5 環性グアニジン 天然物 crambescidin 359 （7）及び 3 環性グアニジ ン天然物 batzelladineD（11）の全合成を行った.

\section{Crambescidin 359（7）の全合成 ${ }^{26)}$}

Crambescidin 359（7）は, 海綿 Monanchoraよ
り単離された 5 環性グアニジン化合物で, C14 位か らの側鎖を持たない初めての ptilomycalin A（1) 類縁体である. ${ }^{11)}$ その生物活性についてはほとんど 報告がなく， 1 及びその類縁体との比較において大 変興味が持たれた. 7 の合成を開始するにあたり, その絶対立体配置は決定されていなかったが 1 と同 様であると推察し, Scheme 3 で述べた手法を基盤 に, 光学活性なニトロン 38 及びオレフィン 39,42 よりピロリジン誘導体 $\mathbf{4 5}$ を経て合成することを計 画した（Scheme 5).

ニトロン 38 とオレフィン 39 との 1,3-双極子環 化反応により 40 を得, Barton-McCombie 法によ り水酸基を除去し 41 を得た. 41 に対し mCPBA を 作用させニトロンを位置選択的に得, 続くオレフィ ン 42 との再度の 1,3 -双極子環化反応により 43 を 得た.さらに 43 に対し 1 当量の $\mathrm{mCPBA}$ を塩化入 チレン中 $0{ }^{\circ} \mathrm{C}$ で作用させ $\mathbf{4 4}$ を得た。 ニトロン 44 に 対し $\mathrm{NaBH}_{4}$ を用いて還元反応を行ったところ, $7: 1$ の選択性で望む cis 体が優先して得られてきた. Cis 体をシリカゲルカラムにより分離精製した後, ヒドロキシルアミンを Mo (CO) ${ }_{6}^{27)}$ により還元しピ ロリジン 45 とし, 続くグアニジノ化及び TPAP 酸 化によりジケトン 47 を得た。 47 に対しまず塩酸一 

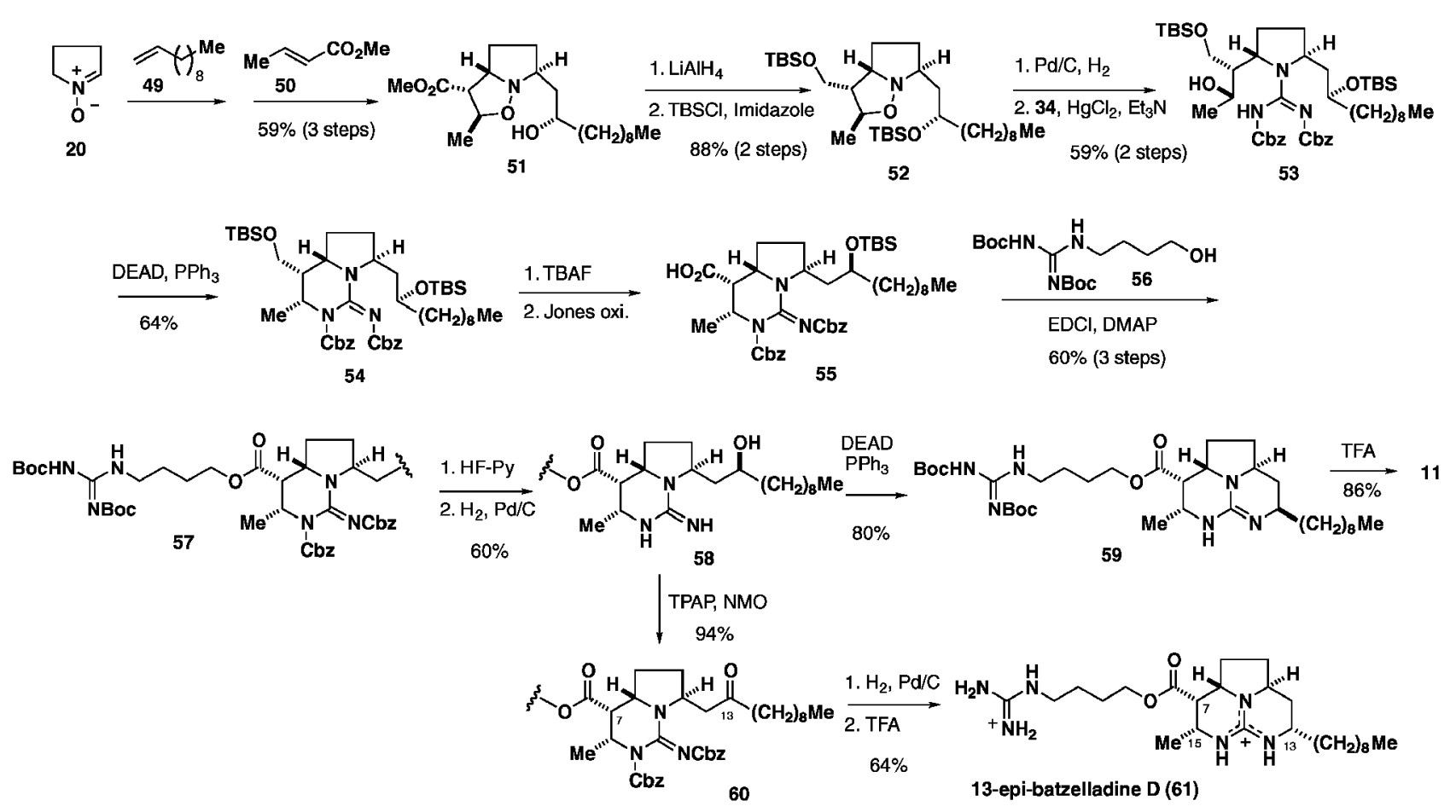

Scheme 6. Total Synthesis of Batzelladine D (11) and 13-epi-Batzelladine D (61)

メタノールを作用させたところ，望む 7 は得られず 48 が主生成物として得られてきた。種々条件を検 討した結果, 47 に対しトルエン中 CSA を 1 当量反 応させることにより 7 をカンファースルフォネート として得ることができた．合成した 7 の対アニオン は, $\mathrm{NaBF}_{4}$ 飽和水溶液を作用させることにより $\mathrm{BF}_{4}$ へ, さらに $\mathrm{NHCl}_{4}$ 飽和水溶液を作用させ $\mathrm{Cl}$ へ変 換した. 合成した 7 の種々のスペクトルデータは, 天然物のそれと完全に一致した。 また合成品 7 の旋 光度が $-8^{\circ}$ (天然物 : $-9^{\circ}$ ) であることから, 天然 物の絶対立体配置は合成品と同一であることが明ら かとなった. ${ }^{28)}$

Ptilomycalin A (1) は, $\mathrm{Na}^{+}, \mathrm{K}^{+}, \mathrm{Ca}^{2+}-$ ATPase をATP と競合的に阻害することが知られている $\left(\mathrm{Na}^{+}, \mathrm{K}^{+}: \mathrm{IC}_{50} 2 \mu \mathrm{M}, \mathrm{Ca}^{2+}: \mathrm{IC}_{50} 5 \mu \mathrm{M}\right)$. $\left.{ }^{6}\right)$ Crambescidine 359 （7）は，1のスペルミジンを含む長鎖ア ルキル側鎖を持たない化合物であり，その生物活性 は 1 の母核である 5 環性グアニジン骨格の生物活性 への寄与を知る上で大変興味が持たれる. そこで次 に 7 の $\mathrm{Ca}^{2+}$-ATPase 阻害活性について調べた。 そ の結果, 7 は $100 \mu \mathrm{M}$ において $\mathrm{Ca}^{2+}-\mathrm{ATPase}$ を非拮 抗的に $50 \%$ 阻害することが分つた。 以上より 1 の $\mathrm{Ca}^{2+}$-ATPase 阻害活性発現には，スペルミジンを
含む長鎖アルキル側鎖も重要な役割を果たしている ことが明らかとなつた. ${ }^{29)}$ 現在さらに詳しく 1 の構 造活性相関について検討を行っている.

\section{Batzelladine D（11）の全合成 ${ }^{30)}$}

次に batzelladine D（11）の全合成について研究 を行った。 11 は 3 環性グアニジン骨格上に $5 つ$ の 不斉炭素を有する。 Overman らによる最初の全合 成が報告されているが, ${ }^{31)} 7$ 位及び 15 位の立体化学 の制御は十分ではない。そこで Scheme 4 で開発し た手法を用い，11 の全合成を行った（Scheme 6).

ニトロン 20 に対して 1-undecene (49), methyl crotonate（50） を順次用いる連続的 1,3-双極子環 化反応によりイソキサゾリジン 51 を立体選択的に 得た。この連続的な 1,3-双極子環化反応により 11 の持つ 5 つの不斉炭素の立体化学すべてを一挙に制 御することができた. 51 のエステル基を還元後 2 つの水酸基を TBS エーテルで保護し 52 とし， N$\mathrm{O}$ 結合の還元，続くグアニジノ基の導入を行い $\mathbf{5 3}$ を得た. 53 に対し DEAD, $\mathrm{PPh}_{3}$ を作用させたとこ ろ閉環反応が進行し，2 環性グアニジン 54 が得ら れた。 そこで TBAFにより 1 級 TBS エーテルのみ を選択的に脱保護し，ついで Jones 酸化により 1 級 水酸基を酸化しカルボン酸 $\mathbf{5 5}$ を得た。次に別途合 
成したグアニジンアルコール 56 とカルボン酸 55 を EDCI を用いて反応させたところ，57を 3 行程 60 \%の収率で得ることができた。 得られた 57 に対し TBS 基及び $\mathrm{Cbz}$ 基の脱保護を行い $\mathbf{5 8}$ とし，ついで 再度 $\mathrm{DEAD}, \mathrm{PPh}_{3}$ を作用させることにより望む 3 環性グアニジン化合物 $\mathbf{5 9}$ を $80 \%$ の収率で得ること ができた。 最後に TFA により Boc 基の脱保護を行 い Batzelladine D（11）を合成することができた. また 58 に対し，TPAP を用いて 2 級水酸基を酸化 しケトン 60 とした後, 水素雾囲気下, パラジウム 炭素を用い $\mathrm{Cbz}$ 基の脱保護を行ったところ, 脱保 護と同時にイミンの形成反応，さらに続くイミンの 還元反応が一挙に進行し，13-epi-batzelladine D （61）を合成することができた.

本合成ルートにおいて興味深いことに, 三環性グ アニジン骨格を有するカルボン酸 62 もしくはエス テル 63 に対しグアニジンアルコール 56 を反応させ ても, エステル化やエステル交換反応が全く進行し なかった（Scheme 7)。これは 7 位カルボキシル基 がアキシャル配置であり, 反応性に乏しいためと考 えられる. ${ }^{32-34)}$ 現在，合成した天然物 11，13-epi 体 61, 及び 11 の合成類縁化合物の生物活性につい て，検討を行っている.

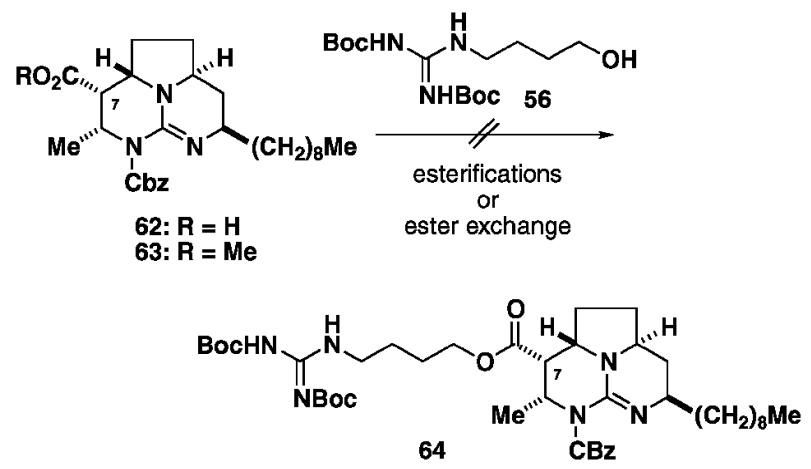

Scheme 7. Synthetic Approach of $\mathbf{1 1}$ from Tricyclic Guanidine 62 and 63

\section{6. 新規グアニジン型不斉有機分子触媒の開発}

現在, 地球規模での環境污染に対する取り組みの 1 つとして, 有機合成化学の分野において, 環境へ の負荷が少ない試薬, 溶媒の開発研究が重要になつ てきている，有機分子触媒は，現在盛んに用いられ ている（有機）金属系触媒と異なり, 水や酸素に対 して安定で, 反応終了後も触媒が劣化することなく 回収され再利用できることから, 環境調和型の触媒
と言える，有機分子触媒としては，シンコナアルカ ロイド誘導体，ビナフチル化合物誘導体，及び酒石 酸誘導体の 4 級アンモニウム塩などが知られ, ${ }^{35)}$ ア ルドール反応，アルキル化反応，Baylis-Hillman 反応，Darzens 反応及びエポキシ化反応などに対し て高い反応活性を示し，高い不斉収率を得ることの できる触媒も報告されている，新しい有機分子触媒 を開発し，新規な反応や不斉反応を開拓すること は, 有機合成化学における重要な研究課題の 1 つで あると考えられる。このような背景のもと, 次に我 々は独自の有機分子触媒を設計し, 新たな不斉反応 を開発することを計画した。そこで新規有機分子触 媒の開発を行うにあたり，その活性中心構造にグア ニジン骨格を用いることとした.グアニジン化合物 は先に述べた通り, リン酸エステルやカルボン酸と 強い水素結合等を形成する強力なアニオンレセプ ターであり, 生体内においては, タンパク質の 3 次 元構造を安定化すると共に, いくつかの生体反応に おいてその重要な反応活性部位として関与している ことから，グアニジン化合物が反応基質を活性化し たり, 塩基性試薬として機能することを期待し た. ${ }^{36,37)}$

新たなグアニジン試薬として，先に全合成を行っ た Crambescidin 359（7）の母核骨格をもとに， $C_{2}$ 対称な 5 環性グアニジン化合物 65 を設計した (Fig. 3). 65 は, 反応基質を活性化するグアニジン 構造近傍に不斉空間を有することから，65 を触媒 とする種々の反応における不斉誘起が期待できると 考えた.

実際には，新規グアニジン触媒として 69a-d 合成を行った（Fig. 4). ${ }^{21,38)} \mathbf{6 9} \mathbf{a} 一 \mathbf{d}$ の合成は, 酒石 酸より得られる光学活性なニトロン 66 に対し, オ レフィン化合物 25, 39,67，68 をそれぞれ連続的な 1,3-双極子環化反応に付すことにより合成した. 得 られた 5 環性グアニジン化合物 69a-d はいずれも 結晶として得られたため, 各々について X 線結晶 構造解析を行った．その結果 69a，69b，69d はグア ニジン周辺のキャビティがクローズ型であるのに対 し 69c はオープン型のキャビティを有していること が分った。これは環状グアニジン部とエーテル環上 の置換基との間に生ずる 1,3-ジアキシャル反発に よるものである．また 69d は，69a や 69bに比べ, より深いキャビティを有していることも明らかとな 


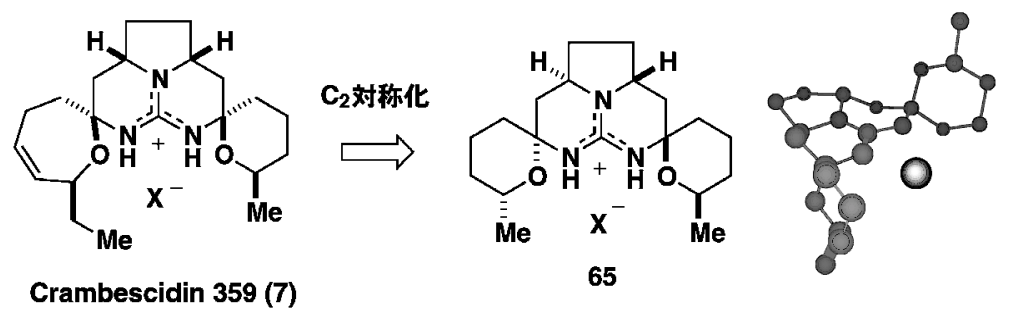

Fig. 3. Design of Novel Guanidine Catalyst

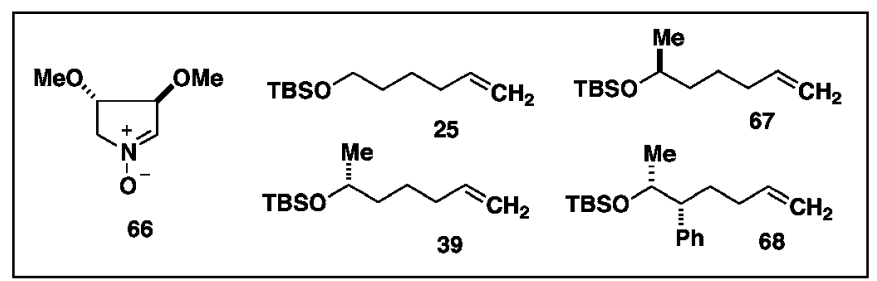

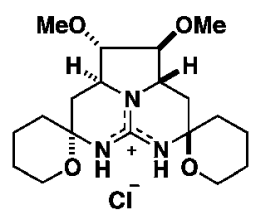

$69 a$

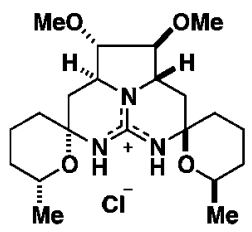

$69 b$

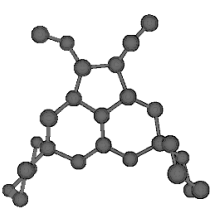

top view

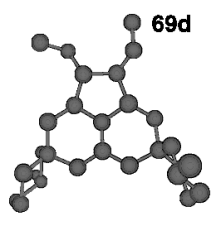

top view

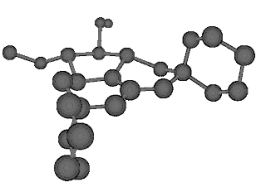

side view

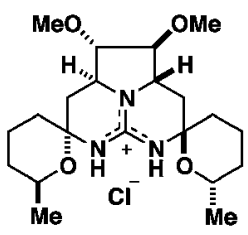

$69 c$

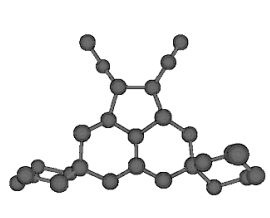

top view

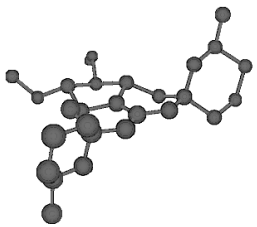

side view

Fig. 4. Preparation of Pentacyclic Guanidine Compounds 69

つた (Fig. 4, top view). 以上のことから 5 環性グ アニジン化合物 69 においては, エーテル環上の置 換基の立体化学や位置を変えることにより, グアニ ジン周囲のキャビティの「大きさ」や「深さ」を自 在に変えることができることが分つた．また 69 の エーテル環上の置換基は, 環状グアニジン平面の上 下に張り出しているエーテル環の立体的な嵩高さ を, さらに増幅する効果が期待できることも同時に 予想された（Fig. 4, side view）.

7. 5 環性グアニジン触媒 69 を用いた炭素一炭 素結合反応

グアニジン化合物を触媒とする反応として，その 塩基性や塩基形成能に基づくいくつかの炭素一炭素 結合反応, 例えばマイケル反応, ストレッカー反
応，ヘンリー反応などが知られている. ${ }^{36,39-42)}$ そこ で合成した 5 環性グアニジン化合物 69 について, 次にこれを触媒とする炭素一炭素の結合形成反応に ついて検討を行つた。

まず，ピロリジン（71）を求核剤とする $\gamma$-クロ トノラクトン（70）へのヘテロマイケル反応につい て検討を行った（Table 1). ${ }^{38)}$ この反応は既に Mendoza, Murphyによりグアニジン触媒を用いた 検討がなされ，グアニジウム塩がこの反応を触媒的 に加速し，この時グアニジウム塩の対アニオンに依 存して, その反応の加速効果が異なることを報告し ている. ${ }^{39,40)}$

ピロリジン（71）及び $\gamma$ クロトノラクトン（70） を含む重クロロホルム溶液中, 合成した 5 環性グア 
Table 1. Hetero Michael Reaction in the Presence of 69

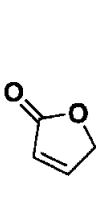

70

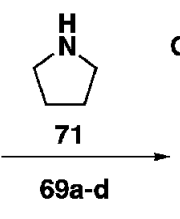

$\mathrm{CHCl}_{3}, 0.3 \mathrm{M}$

$190 \mathrm{~min}$ (no catalyst)

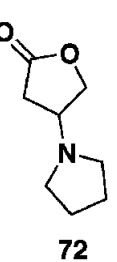

72

\begin{tabular}{cccc}
\hline \hline $69 a$ & $69 b$ & $69 c$ & $69 d$ \\
\hline $2.4-$-fold & $2.3-$-fold & $8.3-$-fold & 6.3 -fold \\
$(82 \mathrm{~min})$ & $(78 \mathrm{~min})$ & $(23 \mathrm{~min})$ & $(30 \mathrm{~min})$ \\
\hline
\end{tabular}

ニジン化合物 $69 \mathrm{a}-\mathbf{d}$ を 0.1 当量加え, そのへテロ マイケル反応の反応速度を核磁気共鳴スペクトルを 用いて追跡した。 その結果, $69 \mathbf{a}$ - $d$ のいずれのグ アニジン化合物も, 触媒を加えない時と比較してこ のヘテロマイケル反応を加速し, 特に触媒のキャビ ティの大きさに依存して反応を加速する効果がある ことが分つた，すなわちオープン型のキャビティを 有する 69c は, クローズ型のキャビティを有する 69a, 69b に比べて約 4 倍もの反応加速効果を示し た. 興味深いことに, クローズ型で深いキャビティ を有する 69d は， 69c とほぼ同程度の反応加速効果 を示した。これは, 恐らく 69d のフェニル基と反 応基質 70 との間に生ずる $\pi$ - $\pi$ 相互作用により, 反応基質をグアニジノ基近傍に，より速く取り込む ことができるためと考えられる. 本反応では生成物 の不斉誘起は観察されなかったものの, このへテロ マイケル反応における触媒 69 の反応加速効果が, そのキャビティの構造や大きさに依存することを見 い出した.

次に， 69a-c を触媒とする，グリシンイミンエ ステル誘導体 $\mathbf{7 3}$ に対するアルキル化反応について 検討した（Table 2). ${ }^{43)}$ 本反応は，4 級アンモニウ 厶塩を相関移動触媒として用いた多くの研究報告が あるが，グアニジウム塩を触媒とする例は報告され ていない.

そこで塩化メチレン-1M $\mathrm{KOH}$ 水溶液 2 層系中, グアニジン化合物 69 触媒下でのグリシンイミン 73 に対するベンジル化反応を検討した，その結果，触 媒として 69b を用いた場合に, 高い不斉収率（90 \% ee）でベンジル化された 74a が生成することが 分つた。一方, 69a 及び 69c を触媒として用いた場
Table 2. Alkylation of $\mathbf{7 3}$ in the Presence of $\mathbf{6 9}$
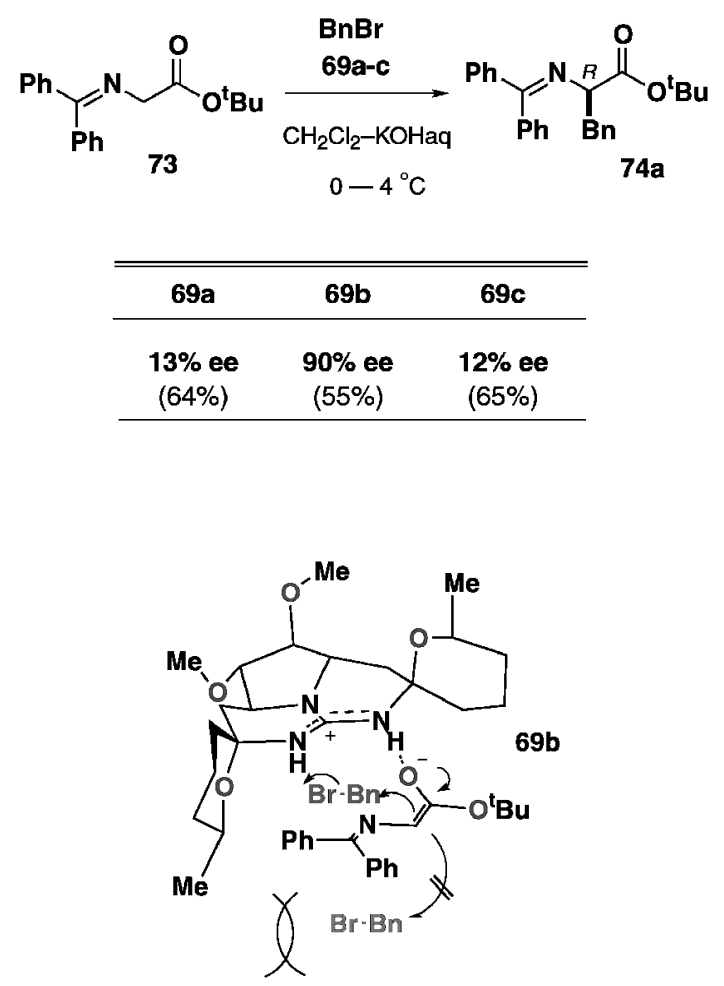

Fig. 5. Mechanism of the Guanidine Catalyzed Alkylation Reaction

合には，生成した 74a の不斉収率はそれぞれ 10\% 程度であった。

この反応においては, 反応基質であるグリシンイ ミン 73 のエノラートが触媒 69 と複合体を形成し, 求電子試薬であるベンジルブロマイドがこの複合体 に近づくときに立体障害の少ない側から接近するた め，生成物における不斉が誘起されたと考えられる (Fig. 5). この際 69b を用いた場合にのみ, 高い不 斉收率で 74a が得られたことから，この反応におい ては，グアニジン触媒のクローズ型構造とともに エーテル環上の置換基であるメチル基が，不斉発現 に重要な役割を果たしていることが明らかとなった。

そこで次に 69bを用いて，種々のアルキルハラ イドによる 73 のアルキル化反応を検討した（Table 3)。その結果，いずれの場合にも高い不斉収率（76 一90\% ee）でアルキル化された $\mathbf{7 4}$ が得られること が分つた. 現在, 開発したグアニジン触媒の他の反 応への応用, グアニジン触媒の更なる改良について 精力的に検討を行っている.

8. おわりに

以上本稿では，新規でユニークな骨格を有する海 
Table 3. Alkylation of $\mathbf{7 3}$ with Electrophiles in the Presence of $69 \mathrm{~b}$

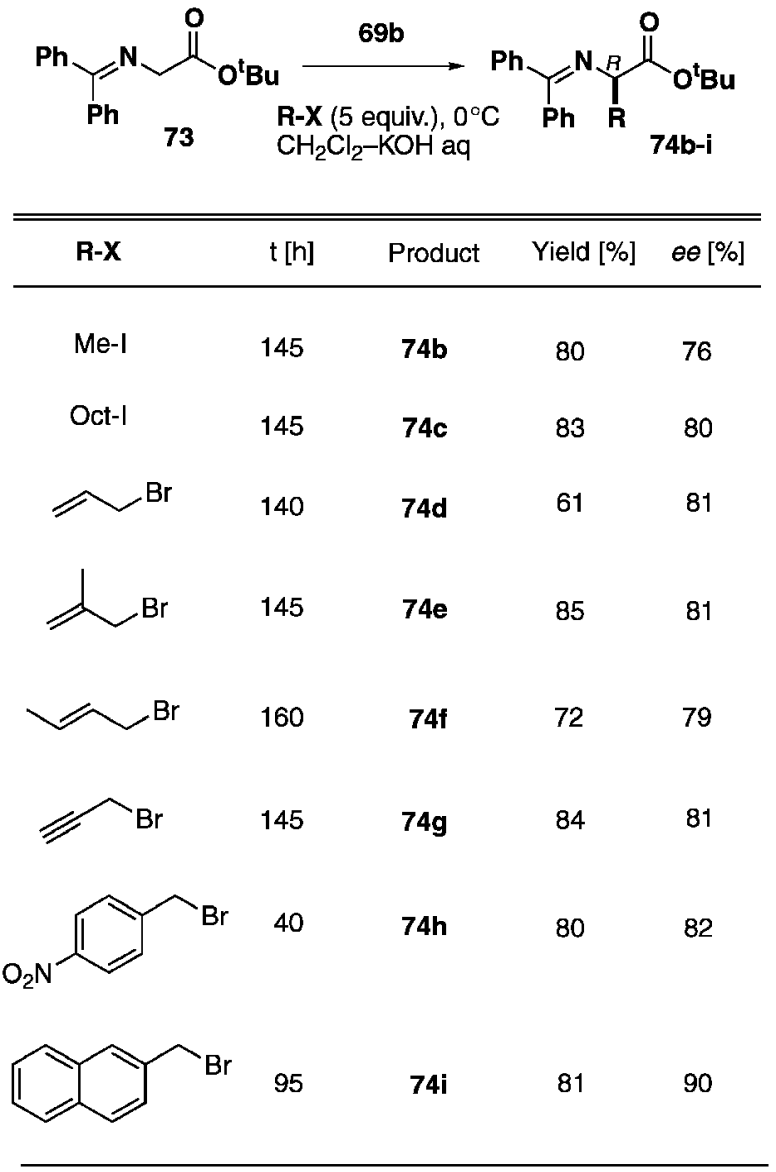

産環状グアニジン系天然物の合成研究において, 連 続する 1,3-双極子環化反応を鍵反応とする，母核 骨格の立体選択的合成法の開発研究について述べ, さらに本手法を基盤とした，crambescidin 359 (7) の初めての全合成, batzelladine D（11）の立体選 択的全合成研究についてその経過を述べた。また, 後半では，全合成に成功した crambescidin 359 (7) の母核骨格をもとに設計合成した，新規グアニジン 系有機分子触媒 69 の開発之, その不斉反応への展 開について述べた。 今回合成研究を行つた一連のグ アニジン化合物は, 非常に多彩で強い生理活性を有 することから, 全合成研究を基盤とした構造活性相 関研究を経て, 様々なバイオプローブとしての展開 が期待される. また後半で述べた, 新たな有機分子 触媒の開発研究は, 今後有機合成化学の研究分野に おいて, 益々その重要性が増してくると考えられ る. 本研究で得られた知見をもとに, さらに有用で 高活性な有機分子触媒の開発を行っていきたい.
謝辞 理化学研究所 中田 忠 主任研究員, 東 京大学分子細胞生物学研究所 橋本祐一 教授には, 終始ご指導ご助言を賜りました。ここに厚く御礼申 し上げます。また本研究を遂行するにあたり, 日夜 献身的に研究を行ってくれた共同研究者諸氏, 特に Angelina Georgieva 博士，石渡貴徳氏，喜多哲也氏 に深く感謝いたします。本研究は, 文部科学省科研 費, 薬学研究奨励財団, 有機合成化学協会研究企画 賞（東レ）の援助を賜りました. 併せて御礼申し上 げます。

\section{REFERENCES}

1) Andraos J., Kresge A. J., J. Am. Chem. Soc., 114, 5643-5646 (1992).

2) Galan A., Andreu D., Echavarrenm A. M., Prados P., de Mendoza J., J. Am. Chem. Soc., 114, 1511-1512 (1992).

3) Kashman Y., Hirsh S., McConnell O. J., Ohtani I., Kusumi T., Kakisawa H., J. Am. Chem. Soc., 111, 8925-8926 (1989).

4) Ohtani I., Kusumi T., Kakisawa H., Kashman Y., Hirsh S., J. Am. Chem. Soc., 114, 84728479 (1992).

5) Ohtani I., Kusumi T., Kakisawa H., Tetrahedron Lett., 33, 2525-2528 (1992).

6) Ohizumi Y., Sasaki S., Kusumi T., Ohtani I. I., Eur. J. Pharmacol., 310, 95-98 (1994).

7) Jares-Erijman E. A., Sakai R., Rinehart K. L., J. Org. Chem., 56, 5712-5715 (1991).

8) Jares-Erijman E. A., Ingrum A. L., Carney J. R., Rinehart K. L., Sakai R., J. Org. Chem., 58, 4805-4808 (1993).

9) Murphy P. J., Williams H. L., Hibbs D. E., Hursthouse M. B., Malik K. M. A., Chem. Commun., 445-447 (1996).

10) Palagiano E., De Marino S., Minale L., Riccio R., Zollo F., Iorizzi M., Carre J. B., Debitus C., Lucarain L., Provost J., Tetrahedron, 51, 3675-3682 (1995).

11) Braekman J. C., Daloze D., Tavares R., Hajdu E., Van Soest R. W. M., J. Nat. Prod., 63, 193-196 (2000).

12) Patil A. D., Kumar N. V., Kokke W. C., Bean M. F., Freyer A. J., DeBrosse C., Mai S., Truneh A., Faulkner D. J., Carte B., Breen A. L., Hertzberg R. P., Johnson R. K., Westley J. W., Potts B. C. M., J. Org. Chem., 60, 
1182-1188 (1995).

13) Snider B. B., Chen J., Patil A. D., Freyer, A. J., Tetrahedron Lett., 37, 6977-6980 (1996) .

14) Patil A. D., Freyer A. J., Taylor P. B., Carte B., Zuber G., Johnson R. K., Faulkner D. J., J. Org. Chem., 62, 1814-1819 (1997) .

15) Black G. P., Murphy P. J., Walshe N. D. A., Tetrahedron, 54, 9481-9488 (1998).

16) Black G. P., Murphy P. J., Thornhill A. J., Walshe N. D. A., Zanetti C., Tetrahedron, 55, 6547-6554 (1999).

17) Snider B. B., Busuyek M. V., J. Nat. Prod., 62, 1707-1711 (1999).

18) Cohen F., Overman L. E., J. Am. Chem. Soc., 123, 10782-10783 (2001).

19) Snider B. B., Shi Z., J. Am. Chem. Soc., 116, 549-557 (1994).

20) Murphy P. J., Williams H. L., Hursthouse M. B., Malik K. M. A., J. Chem. Soc., Chem. Commun., 119-120 (1994).

21) Nagasawa K., Georgieva A., Nakata T., Tetrahedron, 56, 187-192 (2000) .

22) Nagasawa K., Koshino H., Nakata T., Tetrahedron Lett., 42, 4155-4158 (2001).

23) Tufariello J. J., Mullen G. B., Tegeler J. J., Trybulski E. J., Wong S. C., Ali S. A., J. Am. Chem. Soc., 101, 2435-2442 (1979).

24) Ali S. A., Wazeer M. I. M., Tetrahedron, 49, 4339-4354 (1993).

25) McAlpine I. J., Armstrong R. W., Tetrahedron Lett., 41, 1849-1853 (2000).

26) Nagasawa K., Georgieva A., Koshino H., Nakata T., Kita T., Hashimoto Y., Org. Lett., 4, 177-180 (2002).

27) Ritter A. R., Miller M. J., J. Org. Chem., 59, 4602-4611 (1994).

28) Murphy group recently succeeded in the total synthesis of 7. Moore C. G., Murphy P. J., Williams H. L., McGown A. T., Smith N. K., Tetrahedron Lett., 44, 251-254 (2003).
29) Nagasawa K., Georgieva A., Hirai M., Sasaki K., Hashimoto Y., Nakata T., Ohizumi Y., (in preparation).

30) Ishiwata T., Hino T., Koshino H., Hashimoto Y., Nakata T., Nagasawa K., Org. Lett., 4, 2921-2924 (2002).

31) Cohen F., Overman L. E., Sakata S. K. L., Org. Lett., 1, 2169-2172 (1999).

32) Snider B. B., Shi Z., J. Org. Chem., 57, 25262528 (1992).

33) Snider B. B., Chen J., Tetrahedron Lett., 39, 5697-5700 (1998).

34) Nagasawa K., Ishiwata T., Hashimoto Y., Nakata T., Tetrahedron Lett., 43, 6383-6385 (2002).

35) Shibuguchi T., Fukuta Y., Akachi Y., Sekine A., Ohshima T., Shibasaki M., Tetrahedron Lett., 43, 9539-9543 (2002), and references cited therein.

36) Ishikawa T., Isobe T., Chem. Eur. J., 8, 552557 (2002).

37) Ishikawa T., Isobe T., J. Synth. Org. Chem., Jpn, 61, 58-66 (2003) .

38) Nagasawa K., Georgieva A., Takahashi H., Nakata T., Tetrahedron, 57, 8959-8964 (2001).

39) Alcazar V., Moran J. R., de Mendoza J., Tetrahedron Lett., 36, 3941-3944 (1995) .

40) Howard-Jones A., Murphy P. J., Thomas D. A., Caulkett P. W. R., J. Org. Chem., 64, 1039-1041 (1999).

41) Chinchilla R., Najera C., Sanchez-Agullo P., Tetrahedron Asymmetry, 5, 1393-1402 (1994).

42) Iyer M. S., Gigstad K. M., Namdev N. D., Lipton M., J. Am. Chem. Soc., 118, 49104911 (1996).

43) Kita T., Georgieva A., Hashimoto Y., Nakata T., Nagasawa K., Angew. Chem. Int. Ed., 41, 2832-2834 (2002). 